\title{
IN SEARCH OF LOST TIME: THE NEOCLASSICAL SYNTHESIS
}

\author{
Michel De Vroey ${ }^{1}$ e Pedro Garcia Duarte ${ }^{2}$
}

\begin{abstract}
RESUMO:
A macroeconomia de hoje em dia é chamada de nova síntese neoclássica, sugerindo que ela representa uma reencarnação da síntese neoclássica da década de 1950. Tal sugestão nos levou a examinar o conteúdo das sínteses "velha" e "nova". Nossa principal conclusão é que a nova síntese tem pouca semelhança com a velha. Além disto, argumentamos que: (a) desde sua origem com Paul Samuelson a síntese neoclássica não tinha um conteúdo definido e nós apresentamos quatro principais deles; (b) em sua interpretação mais pertinente, aquela proposta por Solow e Mankiw, tal síntese representa uma defesa de uma macroeconomia pluralista na qual modelos de curto prazo com desequilíbrio conviveriam lado a lado com modelos de equilíbrio de longo prazo; (c) uma distinção precisa ser feita entre os novos keynesianos de primeira e segunda gerações porque os primeiros defendiam a velha síntese, enquanto que os últimos, com seus modelos DSGE, aderiram à visão Lucasiana de uma macroeconomia baseada em um único modelo básico.
\end{abstract}

Palavras-Chave: síntese neoclássica, nova síntese neoclássica, modelos DSGE, Paul Samuelson, Robert Lucas

\begin{abstract}
:
Present day macroeconomics has been dubbed as the new neoclassical synthesis, suggesting that it constitutes a reincarnation of the neoclassical synthesis of the 1950s. This has prompted us to examine the contents of the 'old' and the 'new' syntheses. Our main conclusion is that the latter bears little resemblance with the former. Additionally, we argue that: (a) from its origins with Samuelson onwards, the neoclassical synthesis had no fixed content and we bring out four main meanings; (b) its most cogent interpretation, defended by Solow and Mankiw, is a plea for a pluralistic macroeconomics, wherein shortperiod market non-clearing models would live side by side with long-period market-clearing models; (c) a distinction should be drawn between first and second generation new Keynesian economists as the former defend the old synthesis while the latter, with their DSGE models, adhere to the Lucasian view of macroeconomics based on a single baseline model.
\end{abstract}

Keywords: neoclassical synthesis, new neoclassical synthesis, DSGE models, Paul Samuelson, Robert Lucas

Área ANPEC: 01

Classificação JEL: B22, B30, E12, E13

\footnotetext{
${ }^{1}$ Université Catholique de Louvain, Belgium (michel.devroey@ uclouvain.be).

${ }^{2}$ Department of Economics, University of São Paulo, Brazil (pgduarte@usp.br). I am grateful to the São Paulo Research Foundation (Fapesp), Brazil, and the Brazilian National Council for Scientific and Technological Development (CNPq) for financial support.
} 


\section{IN SEARCH OF LOST TIME: THE NEOCLASSICAL SYNTHESIS}

\section{Introduction}

Since its inception, macroeconomics has witnessed an alternation between phases of consensus and dissent. In the first years (from the 1940s to the end 1960s) macroeconomists claimed to have reached a consensus because they saw themselves as Keynesians both in terms of their method of analysis and of their policy standpoint. Then, in the 1970s, Lucas and other new classical macroeconomists launched a fierce attack on Keynesian macroeconomics. Two long decades of strong rivalry between Keynesians and anti-Keynesians (first, new classical and, next, real business cycle macroeconomists) ensued. In the mid 1990s, the wind changed, and the earlier opposed tribes decided to bury the war hatchets. A new consensus arose. In the literature, these two consensus episodes are bound under the terms of 'neoclassical synthesis' and 'new neoclassical synthesis,' both taken as well established viewpoints. The former expression is credited to Paul Samuelson in the third edition of his undergraduate textbook, Economics (Samuelson 1955), the latter is due to Marvin Goodfriend and Robert King (1997).

Our initial goal was to compare the 'old' and the 'new' syntheses. When starting to work on it, we encountered two conundrums. First, we undertook a JSTOR search about the use frequency of the neoclassical synthesis notion during the heyday of Keynesian macroeconomics, when this frequency should have been the highest. To our surprise, we discovered that the term was scarcely used as if the neoclassical label was a retrospective projection from the present onto the past, a backreading occurrence. Second, while the content of the new neoclassical synthesis is clear-cut, that of the old synthesis turned out to be elusive. It is unclear whether it designates a general methodological or policy consensus or a precise theoretical point. And, as far as the latter is concerned, several different meanings turn out to have coexisted. These two factors led us to shift our inquiry from a confrontation between those two historically dated viewpoints in our discipline toward an inquiry focused on the first of them.

In Section 1, we confront the meaning of the neoclassical synthesis expression at the time when it was launched by Samuelson in the 1950s with its present meaning, and argue that a long journey has taken place in-between. In Section 2 we expose the results of our JSTOR search, showing how the frequency of occurrences of the term changed over time and making the case that initially it had varied meanings. In Section 3 we draw a distinction between the notions of a consensus and a synthesis, and apply this distinction to the Keynesian macroeconomics. Next, in Section 4, we explore the different meanings that the notion of neoclassical synthesis has received in the literature. This examination will lead us to draw the startling conclusion that the most cogent understanding of the neoclassical synthesis notion, held e.g. by Solow and Mankiw, implies that Keynesian and Walrasian theories should be kept separate rather than being synthetized. In this line, the neoclassical synthesis banner refers to a plea for pluralism in macroeconomics and against its being taken over by the general equilibrium approach. In Section 5, we recount Lucas's assault on the neoclassical synthesis and the retort it triggered from what we shall call first generation new Keynesian economists (to distinguish them from second generation new Keynesianism as associated with DSGE modeling). Finally, in Section 6, we discuss the new neoclassical synthesis of the late 1990s and then fall back on our initial aim of comparing the two syntheses.

\section{From Samuelson's inauguration of the 'neoclassical synthesis' to present-day accounts}

Macroeconomists (and historians of economics) attribute to Samuelson the coinage of the term neoclassical synthesis in the third edition of his Economics textbook in 1955. He did it in a solemn, emphatic, tone, hammering home a 'harmonist ideal' message, to borrow Kerry Pearce and Kevin Hoover's $(1995,201)$ characterization. At the risk of repetition, let us quote several such passages.

Repeatedly in the book I have set forth what I call a 'grand neoclassical synthesis'. This is a synthesis of (1) the valid core of modern income determination with (2) the classical economic principles (Samuelson 1955, VI).

Here at the end of Part Two's analysis of aggregative economics or macroeconomics, it is fitting to formulate an important tenet of modern economics. Neoclassical synthesis: by means of appropriately reinforcing monetary and fiscal policies, our mixed-enterprise 
system can avoid the excesses of boom and slump and can look forward to healthy progressive growth. This fundamental being understood, the paradoxes that robbed the older classical principles dealing with small-scale 'microeconomics' of much of their relevance and validity - these paradoxes will now lose their sting. In short, mastery of the modern analysis of income determination genuinely validates the basic classical pricing principles; and - perhaps for the first time - the economist is justified in saying that the broad cleavage between microeconomics and macroeconomics has been closed (360; emphasis in the original).

In recent years 90 percent of American economists have stopped being 'Keynesian economists' or 'anti-Keynesian economists'. Instead they have worked towards a synthesis of whatever is valuable in older economics and in modern theories of income determination. The result might be called neo-classical synthesis and is accepted in its broad outlines by all but about 5 per cent of extreme left wing and right wing writers (212).

Three claims are made in these quotations: a) that there is a consensus among American economists that monetary and fiscal policy can and should be used for stabilizing the economy and insure full employment; b) that Keynesian theory, here understood as the income-expenditure model, fills the gaps to be found in classical theory; c) that thereby any cleavage between microeconomics and macroeconomics has been closed.

What Samuelson seems to have meant is that the neoclassical synthesis describes a consensus in the profession whereby most of its members, be they macroeconomists or not, adhered to the view that active fiscal and monetary interventions are fine stabilizing tools. The emphasis is thus on an agreement about policy rather than on its theoretical justification. ${ }^{3}$

Samuelson had also an additional motivation for fostering the consensus view: the publication of his textbook and its subsequent revisions encountered fierce opposition by right-wing writers (some of them associated with the MIT Corporation) who saw Samuelson's textbook as a defense of government intervention (some calling the book communist) and as a criticism to free market ideas (Giraud 2011). As Yann Giraud (2011) shows, Samuelson explicitly took a "middle-of-the-road position" in writing and revising his textbook, and such reasonableness and tolerance was used to defend the book against those charges. Much later, in a 1997 article, Samuelson discussed those criticisms: he evoked Lori Tarshis's 1947 textbook, The Elements of Economics, and declared that Tarshis was "almost killed" by "vicious political and personal attacks [from the right] on him as a 'Keynesian-Marxist"” (Samuelson 1997, 158). A similar fate, he continues, almost happened to him: "having tasted blood in trying to root the Tarshis text out of colleges everywhere", the same people turned towards Samuelson book. Being centrist was Samuelson's strategy out of these criticisms. "Interested in maximizing not $P Q$ book revenues but rather $Q$ influence, I could only gain from being eclectic and centrist" (159). ${ }^{5}$

\footnotetext{
${ }^{3}$ Before the official inauguration of the term in 1955, Samuelson toyed with the neoclassical synthesis idea in other contemporary writings. As Pearce and Hoover (1995, pp. 201-2) indicate, in the second edition of the Economics textbook (1951), he already presented the idea of a consensus on economic policy when he wrote that $90 \%$ of economists have stopped being either Keynesian or anti-Keynesian economists. However, here he branded this consensus "neo-classical theory" instead of neoclassical synthesis. Other early articles where either the term or the idea of neoclassical synthesis is present are Samuelson ([1951] 1966, 1952). But in them, he associated completely different meanings to the term: while in the first article he discussed modern fiscal theories and talked about a "general neo-classical theory that incorporates into the classical tradition whatever parts of the Keynesian and neo-Keynesian analysis that seem to possess descriptive validity for the presentday economy" (1271), in the latter he used the term neoclassical synthesis to designate the marginalist revolution of the late nineteenth century (60).

${ }^{4}$ As Pearce and Hoover (1995) argue, Tarshis's book "is often regarded as the first systematically Keynesian textbook" (192), while the first edition of Samuelson's Economics "was not tightly structured around Keynes's own conceptual framework" (186). So it is interesting to note that the inauguration of the neoclassical synthesis as a policy consensus paralleled a process of turning Economics more Keynesian, a process that happened with most macroeconomics textbooks of the late 1940s.

5 Samuelson's centrist strategy of presenting his interventionist ideas as part of a wide consensus in economics (the neoclassical synthesis) was not only noted but also explicitly rejected at the time by one of his most enduring critics E. C. Harwood. In an October 1961 review of the fifth edition of Economics (in a publication of the American Institute for Economic Research, a Massachusetts liberal think tank, titled Economic News), Harwood accused Samuelson to use the idea of a synthesis to give weight to his interventionist ideas: "Perhaps in an effort to add what he considers to be the weight of
} 
Let us now jump in time and wonder how present-day economists understand the neoclassical synthesis notion. Again at the risk of being repetitive, we want to provide the reader with several of such accounts, drawn from the writings of Peter Howitt, N. Gregory Mankiw and Michael Woodford (see also Blanchard 1987, 634-5):

Since it was widely believed that wages were less than fully flexible in the short run, it seemed natural to see Keynesian theory as applying to short run fluctuations and general equilibrium theory as applying to long-run questions in which adjustment problems could safely be ignored. This view came to be known as the 'neoclassical synthesis'. (Howitt 1987, 274).

How to reconcile these two visions of the economy — one founded on Adam Smith's invisible hand and Alfred Marshall's supply and demand curves, the other founded on Keynes's analysis of an economy suffering from insufficient aggregate demand - has been a profound, nagging question since macroeconomics began as a separate field of study. Early Keynesians, such as Samuelson, Modigliani, and Tobin, thought they had reconciled these visions in what is sometimes called the 'neoclassical-Keynesian synthesis.' These economists believed that the classical theory of Smith and Marshall was right in the long run, but the invisible hand could become paralyzed in the short run described by Keynes. (Mankiw 2006, 35).

The mainstream view, after the end of the Depression and especially in America, was what came to be called 'the neoclassical synthesis'. The neoclassical synthesis, as developed by John R. Hicks and Paul A. Samuelson, among others, in the first decade after Keynes wrote, proposed that both the Keynesian theory and neoclassical general equilibrium theory could be viewed as correct, though partial accounts of economic reality. The conventional theory of general competitive equilibrium was argued to correctly explain the determination of prices and quantities in the long run, once wages and prices had had sufficient time to adjust to clear markets.... At the same time, the Keynesian model was argued to explain the short-run effects of both disturbances to the economy and policy interventions, before prices and wages had much time to adjust. The details of how one got from the Keynesian short run to the "classical" long run were not really worked out. ... the 'neoclassical synthesis' allowed postwar Keynesians to maintain that there was no fundamental incompatibility between microeconomic and macroeconomic theory.... (Woodford 1999, 9-10).

All these quotations converge to stating that the neoclassical synthesis's concern is the relation between the short and the long period, the first constituting the domain of study of Keynesian theory as it is characterized with stickiness and market non-clearing, the second the domain of neoclassical theory as it features flexibility and market clearing. Here, unlike in Samuelson's quotations, the emphasis is more on theoretical developments than on a policy consensus. ${ }^{6}$

\section{A JSTOR comparative study of the terms 'neoclassical synthesis' and 'IS-LM model'}

Our aim in this section is to assess the frequency with which the neoclassical synthesis term was used in the literature. To this end, we engaged in a JSTOR inquiry, searching how many times the term

recognized authority to his assertions, Professor Samuelson repeatedly says that most economists agree with various views he offers ... [which lead to] his so-called synthesis of Keynesian and older economics" (p. 3). Harwood later reserves a whole section to the neoclassical synthesis in which he disagreed on methodological grounds with it and with both of the theories being synthesized, following an argument he developed in a book published in that same year by the same Institute (titled Reconstruction of Economics). (“A Betrayal of Intelligence”, in Paul A. Samuelson Papers, David M. Rubenstein Rare Book \& Manuscript Library, Duke University, box 1, folder "MIT Archive Photocopies”). See also Giraud (2011).

${ }^{6}$ While Samuelson had not originally associated the neoclassical synthesis with the compatibility of short- and long-run analyses and of micro and macroeconomics, he did so in a 1963 article where he surveyed the developments in macroeconomics after Keynes. Here, in addition to associating the neoclassical synthesis with a policy consensus (1544), he also presented the synthesis as a theoretical achievement that made Keynesian theory applicable to "the postwar preoccupation with economic development and growth" (Samuelson [1963] 1966, 1543) involving "as much microanalysis as macroanalysis" (1544). 
"neoclassical synthesis" appeared in economics and finance journals. We made a similar search about the use of the IS-LM term looking at percentage of articles mentioning it. ${ }^{7}$ The solid line represents the number of articles containing the term neoclassical synthesis as a percentage of the total number of

Figure 1: Percentage of Articles with "Neoclassical Synthesis" and "IS-LM"

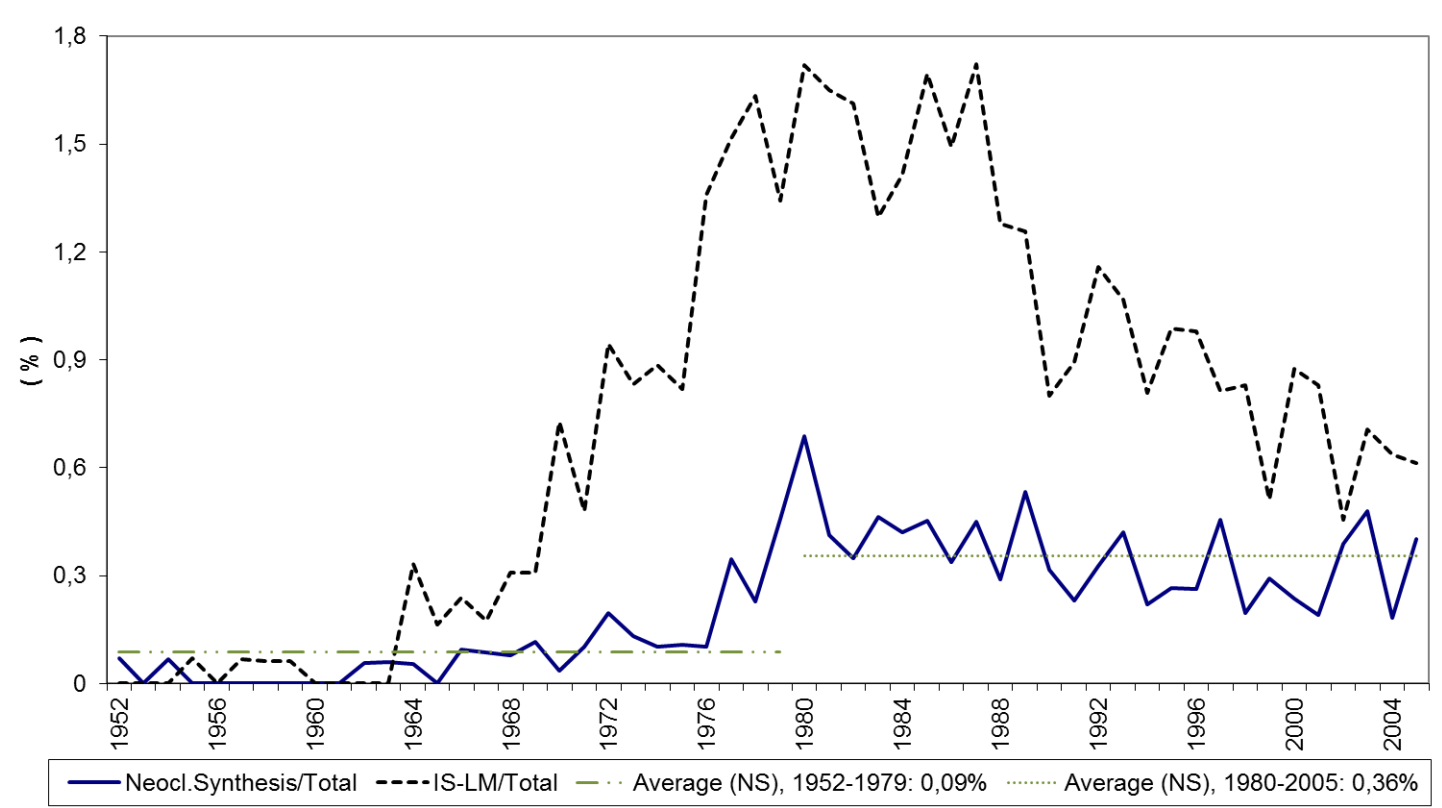

articles in economics and finance journals. The dark dashed line gives the same information about articles containing the term "IS-LM."

There are two observations that are worth making. The first relates to the use of the neoclassical synthesis term. Figure 1 reveals that two periods need to be distinguished in this respect. During the first period, its use remained low. Moreover, most of the references to it were in book reviews or metatheoretical papers. Hardly none mentioning of the term is to be found in the journals at the cutting edge of research. Thus, in what was the heyday of the neoclassical synthesis (say, before the mid-seventies), few were the Keynesian economists who found it useful to put their theoretical practice under the neoclassical synthesis terminology. This is what makes us think that this notion was a backreading phenomenon. ${ }^{8}$ An additional feature of these first years is that authors understood the neoclassical synthesis term in very different ways: three authors use it as meaning stabilization policy (cf. Arrow 1967, 735, and Fand 1969, 559, n. 9), five as a synthesis between Keynesian and neoclassical theory (cf. Sen 1962, 695, Bronfenbrenner 1966, 540, and Loasby 1971, 870), one as the dominant paradigm (Hymer 1968, 720), one as the integration of micro and macroeconomics (Wiles 1973, 388), three occurrences of the term meaning the neoclassical theory of the late 19th century (cf. Samuelson 1952, 60, Johnson 1954, 326, and Tarascio 1974,95 ), and in a host of other meanings, some of which are totally off the mark. ${ }^{9}$

\footnotetext{
${ }^{7}$ At the time of this research, there were one hundred and twenty eight economics journals and seventeen finance journals available in JSTOR. We searched "neoclassical synthesis" (as well as "neo classical synthesis", which includes "neo-classical synthesis") in articles and reviews in these journals, in all languages, from 1952 (the date of the first occurrence, by Samuelson) up to 2005 (when the availability of journal issues in JSTOR starts to decline). We also searched for "IS-LM" and its variants (as "IS/LM", "ISLM" and "IS-LL").

${ }^{8}$ As the JSTOR data basis covers only articles, it might be objected that the neoclassical synthesis term could have had greater use in books and other academic material. Therefore we have looked at the indexes of a random but representative sample of relevant textbooks in macroeconomics. In none of them did we find the occurrence of the term. The books consulted were: Ackley (1961), Denburg and McDougall (1963), Smith (1970), Branson (1972), Gordon (1978), Branson and Litvack (1981), Barro (1987), Dornbush and Fischer (1990), and Hall and Taylor (1991).

${ }^{9}$ Just to give a sense of off-the-mark uses of the term, we take Campbell (1963, 174-5) and Jorgenson (1964, 311-2): the first noted that there were "economic thought" and "economic analysis," and hoped that "proponents of the two views will initiate a useful dialogue, culminating in another kind of "neoclassical synthesis." The latter reviewed Robert Kuenne's book on general equilibrium and stated that its genre belonged to the "neoclassical synthesis," which he defined as "a special kind of
} 
However, things changed in the late 1970s, a period during which standard Keynesian macroeconomics was under attack. Our surmise is that the posterior wider use of the expression in the literature was due to economists referring to Axel Leijonhufvud's and Robert Lucas's writings, as we shall discuss. For different reasons, these two economists exerted an important influence in this reconsideration of macroeconomics. Both of them saw the neoclassical synthesis as a reason for indictment but this common opinion was accompanied with opposite preferences. To Leijonhufvud, a twofold move was needed, first abandoning its neoclassical leg and, second, as far as the Keynesian leg was concerned, replacing 'Keynesian economics' with the 'economics of Keynes' (Leijonhufvud 1968). To Lucas, on the contrary, it was the Keynesian leg that needed to be dispensed with, as, to him, a return to the General Theory was certainly no solution to the failure of Keynesian macroeconomics.

The higher frequency of the neoclassical synthesis term observed during the period of these criticisms was maintained from 1980 onwards up to 2005, with an average of $0,36 \%$ of all articles featuring the term. As the average number of articles published per year in this period was also higher, around 3900, the average number of articles mentioning the neoclassical synthesis was roughly of fourteen per year (in contrast to an average of two articles per year in the period 1952-1979). In the earlier years of the 2000s a further increase in frequency occurred associated with the emergence of the new neoclassical synthesis idea.

Our second observation concerns the relative frequency of the use of the terms, 'neoclassical synthesis' and 'IS-LM' model. From the quotations given in the previous section, it is clear that there currently is a general presumption that the neoclassical synthesis and Keynesian macroeconomics (i.e. ISLM macroeconomics) were part and parcel. If this is so, one might have expected the use of the neoclassical synthesis term go hand in hand with that of the IS-LM model. However, our investigation failed to confirm this expectation. Considering the whole 1952-2005 time span, we see that the neoclassical synthesis term is used, in total, only four hundred and twenty seven times - an average of eight articles per year -, out of the more than one hundred and sixty thousand articles published in this period. This is, we feel, a small number. In comparison, the IS-LM fares much better. ${ }^{10}$ It appears in a bit more than one thousand and four hundred articles in the whole sample, corresponding to an average of twenty six articles per year. Its use boomed from the mid-1960s, reaching a peak of almost $1,8 \%$ of articles in the early 1980s. Figure 1 also shows its sharp decline in the second part of the 1980s, paralleling the emergence of real business cycle macroeconomics. The average number of articles featuring "IS-LM" is around 12 per year in the first period (over a total of three hundred and fifty articles), and 41 in the second one (over a bit more than a thousand articles in this period).

The main lesson to be drawn from this brief bibliometric investigation is that it brings out a conundrum. While retrospective writings refer to the neoclassical synthesis as description of an established way of thinking in macroeconomics in the 1950s and 1960s, it turns out that at the time the name was hardly used to this effect. However, the name absent, the "thing" might still have been present. Our next task is to investigate this possibility.

\section{Disentangling the notions of consensus and synthesis}

As already seen, while Samuelson conceived the neoclassical synthesis term as referring to a policy consensus, present-day economists give it a theoretical content. This difference prompts us to systematize the differences between the notions of consensus and synthesis. Let us start with the latter.

We propose to call synthesis the outcome of a process by which two theoretical analytical frameworks, which at a certain stage are viewed as unrelated, if not irreconcilable, are made compatible or integrated. In other words, a synthesis consists of a new theory merging some elements from the two separate theories at the price of leaving others aside. The identities of each of the involved streams should

mathematical history of economic thought." That the term neoclassical synthesis meant "different things to different economists" was a point already mentioned by Weintraub (1974, 52, fn. 1).

${ }^{10}$ There were relatively few articles containing both "neoclassical synthesis" and "IS-LM": fifty in total (mostly published after 1970), for the entire sample, which represents less than 0,03\% of all articles published in this period, and only $12 \%$ of the articles that featured the term neoclassical synthesis (i.e., out of all articles with "neoclassical synthesis" only $12 \%$ also had "IS-LM" in it). 
be made clear and they are distinct from the identity of the synthesis. To be useful, the synthesis notion should be understood in a narrow sense: the mere assertion that different theories are complementary does not make their relation a synthesis.

Both the 'neoclassical synthesis' and the 'new neoclassical synthesis' terms elude this identification. As far as the second of these expressions is concerned, the matter is easily fixed: the new neoclassical synthesis brings together the new Keynesian and the real business cycle approaches. What about the 'old' neoclassical synthesis? A natural candidate is to view it as a 'Keynesian/neoclassical synthesis', an expression used for example by Mankiw (2006). ${ }^{11}$ However, this appellation is fine only if the 'neoclassical' term is understood as referring to Walrasian theory at the exclusion of Marshallian theory. ${ }^{12}$

As to the notion of a consensus, it describes a state of mind possibly existing in a given scientific community. The condition of its prevailing in macroeconomics, viewed as a specific sub-discipline, is that a majority of macroeconomists agrees on a shared vision about the way in which work in their field should proceed. It is usually accepted that from the 1940s to the mid-1990s, there was a consensus that the Keynesian vision of macroeconomics was the right one. Hence we shall call it the 'Keynesian consensus'. On the contrary, the period from the mid-seventies to mid-nineties macroeconomics witnessed an antagonism between two rival visions, the first generation new Keynesian and the new classical/real business cycle views. From the mid-nineties onwards, a new consensus arose in favor of the DSGE (dynamic stochastic general-equilibrium models) vision gaining the favor of both second generation new Keynesian and RBC economists. Here we shall use the 'DSGE consensus' expression.

Painting with broad brushes, the Keynesian vision is composed of the following tenets:

- Macroeconomics is mainly concerned with short-period analysis.

- Its main objective is to explain involuntary unemployment.

- The IS-LM model is its baseline model.

- Central concepts are disequilibrium, full employment, involuntary unemployment, liquidity preference, price and wage rigidities, output gap, (stable) Phillips curve.

- When considered, expectations are adaptive.

- Empirical assessments proceeded through econometric testing along the lines of Klein and Goldberger (1955).

- Demand activation is the favored policy action.

- Microfoundations are approached in a Marshallian way.

- The neoclassical synthesis is about establishing a link between short- and long-period analyses.

While this sketchy account suffices to fix ideas about the content of the Keynesian vision of macroeconomics, two comments are nonetheless useful. The first concerns microfoundations. The Keynesian vision rests on a Marshallian conception of microfoundations. ${ }^{13}$ It has two features. First, as underlined by Leijonhufvud (2006), optimality is a matter of intention, not of performance. ${ }^{14}$ Second, Marshall saw no harm in starting the analysis from market functions without explicitly deriving these from individual decision-making. Keynes and Keynesian macroeconomists followed suit.

Our second remark bears on the integration of time in the theoretical discourse. Keynesian macroeconomics accepts Marshall's division of time into three categories: the market day, the short and the long period. Each of these time periods can be studied in isolation, their piecing together being

\footnotetext{
${ }^{11}$ See also Colander $(2006,53)$.

12 According to Tony Aspromourgos (1986), the term 'neoclassical' was introduced by Thorstein Veblen in 1900 in a Quarterly Journal of Economics article to characterize Marshallian economics. Aspromourgos (1986, 625) traces to John Hicks (1932) and George Stigler (1941) its extension to designate marginalist theory in general. If Marshallian economics is the quintessence of neoclassical theory, it is hard to exclude Keynesian theory from it since Keynes was treading Marshall's footsteps. As a result, the need of reconciling Keynesian with neoclassical theory falters. Therefore making sense of Mankiw's characterization requires a narrower understanding of the 'neoclassical' adjective.

${ }_{13}^{13}$ Marshall did not use the term microfoundations, but spoke instead of the principle of substitution (Marshall 1920, 361).

14 "[To early neoclassical economists], micro-behaviour was thought of as adaptive. People sought to maximize utility or profit, but these were propositions about intentions, not performance. ... [In modern theory], utility or profit maximization is a statement about actual performance not just motivation" (Leijonhufvud 2006, 1628).
} 
postponed to a further stage of the theoretical inquiry. The statement that macroeconomics is mainly concerned with the short period bears the implication that the long period is not its concern. However, defining macroeconomics as the study of the economy when is off its long-period equilibrium state requires that one has to tackle the issue of the coming together of the short and the long period analyses. One may expect the neoclassical synthesis to pertain to such a matter.

\section{The different meanings of the neoclassical synthesis notion}

In this section, we study the main understandings of the neoclassical synthesis notion (some of which were present in the passages quoted in section 1), leaving aside Samuelson's usage of it and other earlier usages that did not gain currency afterward. They amount to four: (a) the neoclassical synthesis and the IS-LM model are one and the same thing; (b) the neoclassical synthesis designates what Klein and Goldberger achieved when constructing their econometric model: the compatibility of short- and long-run analyses; (c) the neoclassical synthesis refers to the project of combining Keynesian and Walrasian theory; (d) the neoclassical synthesis refers to the view that Keynesian and Walrasian theory should be left existing separately.

\subsection{The selfsameness of the neoclassical synthesis and the IS-LM model}

This first meaning, which many economists have implicitly adopted, consists of stating that the neoclassical synthesis is just another name for the IS-LM model. ${ }^{15}$ Leijonhufvud inaugurated this interpretation in his 1968 book, On Keynesian Economics and the Economics of Keynes, where he wanted to lambast rather than endorse this conception of macroeconomics. To us, this interpretation has little to commend. Whether Keynes's theory was a generalization of classical theory or a special case is irrelevant as neither of these can be conceived as a synthesis in our narrow understanding of the term. Therefore, using the term neoclassical synthesis in this sense brings no plus. Nothing would have been lost had it not been invented.

\subsection{The neoclassical synthesis as the Klein-Goldberger model's achievements}

In the paper in which they introduce the 'new neoclassical synthesis' notion, Goodfriend and King (1997) define the original synthesis as the contribution made in the large scale macroeconometric models that were used in the 1950s and the 1960s - the Brookings model and the Federal Reserve System's MPS model - all of them being the offspring of the Klein-Goldberger model (1955). The argument then boils down to asserting that, without explicitly claiming it, this model marked the achievement of the neoclassical synthesis.

The builders of the theoretical IS-LM model felt authorized to study short-period results in isolation from the long-period results. They hardly looked at the feedback generated by the existence of disequilibrium states and the possible ensuing convergence towards long-period equilibrium. That this limitation needed to be overtaken when it came to construct an empirical model was something that Lawrence Klein had soon realized when starting to think about extending Keynesian theory empirically. In effect, in his eyes, the first priority was to dynamize the IS-LM model. ${ }^{16}$ The road he took was twofold. First, he lagged some of the model's variables in order to get a first-order system of difference equations. Second, since he wanted to verify Keynesian theory and, since involuntary unemployment was one of its central claims, he was particularly interested in the issue of wage formation. He opposed the classical and the Keynesian systems in the following way:

The classical wage adjustment equation:

$\frac{d w}{d t}=f\left(N^{S}-N^{D}\right) ; \quad 0=f(0)$

\footnotetext{
${ }^{15}$ See e.g. McKenna and Zannoni's entry on the neoclassical synthesis in the Encyclopedia of Keynesian Economics (1997, 463-467).

16 "[The Keynesian theoretical system] is an extremely useful pedagogic model for teaching students the main facts about the functioning of the economic mechanism, but it is surely not adequate to explain observed behavior. ... A workable model must be dynamic and institutional; it must reflect processes through time, and it must take into account the main institutional factors affecting the working of any particular system" (Klein 1955, 278-9).
} 
The Keynesian wage adjustment equation:

$\frac{d w}{d t}=f\left(N^{S}-N^{D}\right) ; \quad 0 \neq f(0)$

In words, the classical system converges towards a zero unemployment equilibrium state. In contrast, the Keynesian system converges towards a state of equilibrium featuring an excess of supply over or an excess demand. It took a few years for Klein to go from these insights, which he already exposed in 1948 (Klein 1948), to their implementation in the Klein-Goldberger model.

The fact that this model incorporates a convergence towards long-period equilibrium shows that it achieves an integration of short- and long-period analyses. Hence the temptation of proclaiming that it achieved the neoclassical synthesis. But there is a snag. In the Klein-Goldberger (as well as in subsequent Keynesian empirical models) the economy is supposed to be in a Keynesian state of underemployment both in the short and in the long run (De Vroey and Malgrange 2011). The Klein-Goldberger model, it then turns out, combines Keynesian short-period disequilibrium and Keynesian long-period equilibrium, with the latter still featuring involuntary unemployment. Therefore, this model is effectively a synthesis but not a synthesis between a Keynesian and a non-Keynesian model.

\subsection{The neoclassical synthesis as an attempt at integrating Keynesian and Walrasian theory}

We have pointed out the ambiguity of the 'Keynesian/neoclassical synthesis' terminology when commenting Mankiw's definition (see Note 10). Once it is specified that 'neoclassical' means 'Walrasian', this ambiguity is removed, and the prerequisite of any synthesis program, namely the presence of two apparently opposed types of model, is satisfied. We shall examine two attempts at achieving this integration. The first is the gravitational claim. Its central proposition is that short-period disequilibrium states (the object of analysis of Keynesian theory) converge towards long-period equilibrium states (the object of study of Walrasian theory). It was initiated by Samuelson (him again, but before he introduced the neoclassical synthesis term), in his 1947 book, Foundations of Economic analysis, and later taken up by Don Patinkin in his 1956 book, Money, Interest and Prices. The second strand is due to non-Walrasian equilibrium theorists. Before presenting these two attempts, we need to pause to evoke an initial state of affairs where it was taken for granted that Keynesian theory was an offspring of Walrasian theory.

\subsubsection{The 'Walrasization' of Keynesian theory}

The statement that Keynesian theory and Walrasian theory need to be integrated implies that they are different theories to begin with. This viewpoint did not prevail in the aftermath of the publication of Keynes's General Theory. In effect, a few influential economists such as Lange (1938) and Klein (1947, 56-7; 1950, Chapter 1), made the claim that the IS-LM model was nothing more than a simplified Walrasian model. Were this true, there would be no need to build a synthesis. However, many economists have disputed this claim. In his stern review of Lange's 1944 book, where Lange had exposed the same view as in his 1938 article, and in his 1949 article on Marshallian demand curve, Friedman argued that the Marshallian and the Walrasian approaches were poles apart as far as methodology was concerned. ${ }^{17}$ Though a strong opponent of Keynes, Friedman nonetheless hailed him for being Marshallian, and hence far away from Walras. "Keynes", he wrote, "was a true Marshallian in method" (Friedman and Schwartz 1982, 45) - coming from Friedman, such statement is the nicest compliment conceivable. From a different perspective, Leijonhufvud made the same point in his 1968 book already mentioned. In between these two polar standpoints, a third view emerged, which is our concern in this paper: although Keynesian and Walrasian theory were different, conciliation between them was possible; in other words, they could be synthetized.

\subsubsection{The gravitational view}

Hitherto the name of Samuelson has been evoked only in reference to his introduction of the neoclassical synthesis notion, understood as a policy consensus. Now we turn to another side of Samuelson where he more effectively addresses the theoretical synthesis issue but without using the term: we are referring to his 1947 book, Foundations of Economic Analysis, written before the neoclassical expression came to cross his mind.

\footnotetext{
${ }^{17}$ For references, see De Vroey (2009).
} 
Samuelson's Foundations was mainly a general equilibrium piece. Treading Walras's footsteps, Samuelson distinguished two objects of study, static and dynamic theories. The first described equilibrium as resulting from economic agents solving maximum problems taking prices as parameters, while the second dealt with price adjustments towards equilibrium after the occurrence of shocks, with prices moving in the direction of excess demand functions in proportion to these functions' magnitudes.

Samuelson articulated statics and dynamics through the correspondence principle and his understanding of dynamics rested on the concept of stationary equilibrium, clearly setting out the issues of statics and dynamics and equilibrium in economic theory, against the varied understanding that were present in the literature of the 1930s (see Weintraub 1991, chap. 2). This stationary conception holds that equilibrium is a center of gravity. It supposedly comes into existence only in the long period, and the economy can depart from it in the short period, during which markets disequilibria exist. Whenever this is the case, gravitational forces set in pushing the markets back to equilibrium. It suffices for getting the neoclassical synthesis as a model integrating Keynesian and Walrasian theory to assign the Keynesian label to the disequilibrium states and the Walrasian label to the center of gravity. To give flesh to this integrative insight, Samuelson wrote down a time derivative meant to capture the sluggishness idea, and he stopped there.

What was lacking, however, is an attempt at demonstrating that the tâtonnement process from disequilibrium to equilibrium does its job properly. Patinkin undertook this task in the Keynesian chapters of his 1956 book, Money, Interest and Prices. In in these two chapters (chapters 13 and 14), Patinkin wanted to use the Walrasian conceptual apparatus that he studied in the preceding chapters to reconstruct the central message of Keynes's General Theory, what for him meant to explain involuntary unemployment. Although Patinkin did not state that his argumentation purported to implement the neoclassical synthesis as conceived of in Samuelson's Foundations, this is exactly what it amounted to. ${ }^{18}$

The hallmark of Patinkin's theory of involuntary unemployment is that it is a disequilibrium phenomenon, the existence of which is limited to the re-equilibration time span separating two successive equilibria. Its importance thus hinges on the slowness of the adjustment process. Starting from a state of equilibrium, Patinkin assumes that an increase in the demand for bonds occurs, the effect of which is to decrease the demand for commodities. As to what happens next, it depends on whether one reasons in Walrasian or in Keynesian terms. In the Walrasian framework, the adjustment process in the goods market operates quickly. As a result, a new equilibrium is rapidly established and there is no unemployment. ${ }^{19}$ In contrast, in the Keynesian framework, this adjustment process is assumed to occur slowly. The proximate effect of the decrease in demand for goods is that supply exceeds demand. Firms' first reaction is to pile up inventories. After a while, according to Patinkin, when inventories become too large they have no choice but to decrease production. As a result, their demand for labor diminishes - that is, the 'notional' demand for labor, to use later terminology, ceases to be operative and is replaced with 'effective' demand. Trading in the labor market takes place off the supply curve, which is tantamount to involuntary unemployment.

Patinkin is adamant that, in this account, prices are sluggish rather than rigid. To him, the state of involuntary unemployment so created should not be viewed as a position of equilibrium able to perpetuate itself. Its transitory existence is due to the fact that a decline in the prices of goods is going to occur. As a result the real-balance effect will start to operate so that the economy will eventually be brought back to equilibrium. The point that matters for our assessment is that, according to Patinkin, the equilibrium allocation attained at the end of the slow adjustment process will be the same as that attained under the instantaneous adjustment assumption. If this is true, then Keynesian outcomes indeed gravitate towards the Walrasian equilibrium state, and the Keynes-Walras integration interpretation of the neoclassical synthesis is vindicated.

Unfortunately, Patinkin's reasoning cannot win the day. In effect, in the Keynesian chapters of his book Patinkin drifts away from the Walrasian principles he admitted in its initial chapters. As

\footnotetext{
${ }^{18}$ Lucas later characterized Patinkin's reasoning as "perhaps the most refined and influential version of what I mean by the term 'neoclassical synthesis"' (Lucas [1980] 1981, 278).

${ }^{19}$ Patinkin refers to a quick adjustment. To all intents and purposes, it should be an instantaneous one.
} 
convincingly argued by Franco Donzelli (2007), Walras had felt compelled to introduce the nodisequilibrium trading rule in order to avoid income effects. By contrast, Patinkin's story is full of disequilibrium trading, but he fails to recognize it generates wealth effects. As a result, the economy does not gravitate towards the Walrasian equilibrium that would have been attained had the adjustment taken place instantaneously. Instead, it converges towards a different allocation. Therefore, in so far as it is admitted that Keynesian theory deals with exchanges at 'false prices', the adjustment from Keynesian disequilibrium states towards the Walrasian center of gravity fails to occur.

\subsubsection{Non-Walrasian equilibrium model}

Here we refer to the modeling strategy associated with the names of Robert Barro and Herschel Grossman (1971), Jacques Drèze (1975), Jean-Pascal Benassy (1975) and Edmond Malinvaud (1977). These models took up the line opened by Patinkin but abandoned his assumption of slow adjustment and replaced it with a full-rigidity assumption. As a result, the idea that Keynesian outcomes gravitate towards the Walrasian equilibrium disappears from the scene. In these models it is assumed that, after having made his first price announcement, the auctioneer is not allowed to change the price vector even if he observes non-zero excess demand functions. In this set-up, the economy ends up in different regimes according to the specific values of the 'false' price vector. Except if the auctioneer has by chance hit the Walrasian price vector at the start, the economy will end up with a non-Walrasian equilibrium allocation. One of these regimes is characterized by excess supply in the goods and labor markets and the accompanying excess demand in the market for the non-produced monetary good. Thus, a Keynesian outcome, with unemployment, is obtained in a Walrasian framework.

This result fits our definition of a synthesis: on the one hand, the pre-synthesis Keynesian model is modified with a move from the IS-LM framework towards a Walrasian set-up. On the other hand, the presynthesis Walrasian model is transformed by the introduction of the rigidity assumption, what makes the model 'non-Walrasian'. The model that results of this synthesis has its own properties distinct from those coming from each of the models that were synthesized.

At last, we have here a case of successful synthesis, again without the term being uttered. However, the existence of the non-Walrasian equilibrium approach has been short-lived in macroeconomics. As it is well known, the introduction of the rigidity hypothesis in the Walrasian framework was soon criticized on several grounds - that mutually beneficial trade opportunities are left unexploited, and that there is no reason to invent the auctioneer artifact if he cannot finish his job (Lucas 1987, 52-3).

\subsection{The neoclassical synthesis as the side by side existence of Keynesian and Walrasian analysis}

We now consider a fourth conception endorsed by several leading macroeconomists, such as Franco Modigliani, James Tobin and Robert Solow. It was later taken up by the first generation of new Keynesian economists. The standpoint taken is to defend a partake of territory: the study of the short period is assigned to macroeconomics, that of the long period to microeconomics (i.e. Walrasian general equilibrium theory), the hallmark of the former being market non-clearing, while that of the latter is market clearing. In contrast to the gravitational conception, here the standpoint taken is one of dismissiveness of about the possibility and interest of bridging the Keynesian and the Walrasian approaches. Both of them are considered valid but for different purposes. What is needed, it is argued, is to have different models tailored for the problem at hand. For example, to these economists, it is obvious that in the short run the labor market features involuntary unemployment. General equilibrium being, unfit to tackle this problem, specific models - often small, partial equilibrium ones - are needed for its study. The bottom line is thus the rejection of the hegemony of general equilibrium theory. As told by Solow in an interview, "My belief is that is bad economics to stick rigidly to a single model" (Snowdon and Vane 1999, 283). ${ }^{20}$

The following three quotations, from Robert Solow, James Tobin, and Gregory Mankiw, all testify to this conception:

\footnotetext{
${ }^{20}$ In this respect, it is interesting to note that Solow $(1997 \mathrm{~b}, 594)$ stated that the work of Trevor Swan reminded that "one can be a Keynesian for the short run and a neoclassical for the long run, and this combination of commitments may be the right one."
} 
My general preference is for small, transparent, tailored models, often partial equilibrium, usually aimed at understanding some little piece of the (macro-) economic mechanism (Solow 2008, 246).

According to the synthesis of classical and Keynesian macroeconomics reached by 1960 , Keynesian macroeconomics is short-run. It does not pretend to apply to long-run growth and development. .... In the long run - perhaps with the help of Keynesian policies markets will somehow clear, new workers will get jobs, and the fruits of technological progress will be realised (Tobin 1992, 392).

New Keynesians accept the view of the world summarized by the neoclassical synthesis: the economy can deviate in the short run from its equilibrium level, and monetary and fiscal policy have important influence on real econnomic activity (Mankiw in Snowdon and Vane 1995, 53).

All these quotations hint at what we feel is the core idea of this understanding of the neoclassical synthesis: that it corresponds to a defense of pluralism in macroeconomics. There is a semantic snag, however, because the 'neoclassical (Walrasian)/Keynesian synthesis' amounts in fact to the refusal of establishing a synthesis between these components. Put this differently, while defenders of the third understanding we listed above (gravitation and non-Walrasian equilibrium) want to bridge the Keynes/Walras gulf, 'side-by-side' neoclassical synthesis economists want instead to keep them separate. This semantic oddity notwithstanding, to us the side-by-side conception is the most cogent, be it only by elimination as we have shown that all the others are wanting.

Note finally that, this standpoint taken, nothing prevents the same economist from making contributions to both theories. This has actually been the case for the three economists mentioned above. This also explains, for example, why Solow defines himself as both neoclassical and Keynesian neoclassical when building market-clearing models, Keynesian when building market non-clearing models (Klamer 1984, 3).

\section{Lucas's assault on the neoclassical synthesis and the new Keynesian retort}

Robert Lucas's offensive against Keynesian macroeconomics was multi-dimensional. First, he criticized it for departing from the equilibrium discipline and for giving place to sloppy concepts such as involuntary unemployment and full employment. Second, in the celebrated 'Lucas critique' article (Lucas 1976), he indicted Keynesian macroeconometric models for failing to be 'deeply structural'. Third, he claimed that the 1970 stagflation episode in the US and in other economies had constituted a quasilaboratory confrontation between two models, the Keynesian stable Phillip curve model and the natural rate of unemployment model, from which the second came out as the clear victor. For Lucas, these factors called for the dismissal of the Keynesian vision of macroeconomics.

A declaration of obsolescence apropos the neoclassical synthesis was part of Lucas's wider criticism. It bore both on the neoclassical synthesis, narrowly understood, and the Keynesian vision. Starting with the first aspect, in his paper, "Methods and Problems in Business Cycle Theory" (Lucas [1980] 1981), Lucas argued that it is understandable that earlier economists adhered to the neoclassical synthesis, having in mind its gravitation conception. They lacked the tools for doing serious dynamic analysis. To Lucas, the stationary conception of equilibrium underpinning these economists' analysis of the adjustment process was wanting. By definition, the gravitational analysis is about reaching a predefined equilibrium position and, therefore, cannot come to grips with irreversible changes in the data of the economy (the set of agents and firms, preferences and technology): such changes generate a new equilibrium position to which the economy may tend. Another drawback of the gravitational approach on which Lucas zeroed, is that it leaves the determination of the speed of adjustment to the economist's arbitrariness to the effect that he can give as much or as little importance to disequilibrium as he wishes. ${ }^{21}$

Lucas argued that while Samuelson and Patinkin were not to be blamed for reasoning in terms of the stationary conception of equilibrium, once new concepts and tools became available - originating in

\footnotetext{
${ }^{21}$ Thus, the speed of adjustment was a free parameter that Lucas claimed to have no room in the macroeconomics that he was proposing: for him, parameters ought to be structural, i.e. to describe the microeconomic behavior of individual agents.
} 
the Neo-Walrasian theory à la Arrow-Debreu and new mathematical developments, in particular dynamic programming - it would be foolish to stick with the old conception. ${ }^{22}$ Provided that these developments are integrated, "the idea that an economic system in equilibrium is in any sense 'at rest' is simply an anachronism" (Lucas ([1980] 1981, 287). In this new context, there is no longer any reason for trying to build a synthesis between Keynesian disequilibrium theory and Walrasian equilibrium theory because the latter can perfectly take on board that part of the explanandum that earlier on was assigned to Keynesian theory. The need for two separate theories bearing respectively on the short and the long period now vanishes. Likewise the short-/long- period dyad that reigned so long in economics ceases to be central.

To Lucas, this undoing of neoclassical synthesis was part of the broader undoing of the Keynesian vision of macroeconomics. As a result, with the emergence of a rival vision (known at the time as new classical macroeconomics that would later evolve into the real business cycle theory), the Keynesian consensus started to fall apart. Lucas developed this point both in his 1979 article with Thomas Sargent (Lucas and Sargent 1979) and in a talk given at the Graduate School of Chicago's Annual Management Conference in that same year and entitled no less than "The Death of Keynesian Economics". ${ }^{23}$ In this lecture, Lucas related the emergence of the Keynesian consensus to the Great Depression, which led to a widespread loss of faith in market forces and gave way to the belief that the task of governments was to manage the economy on a year-to-year basis.

The central message of Keynes was that there existed a middle ground between the extremes of socialism and laissez faire capitalism. ... True that [the] economy cannot be left to its own device, but all that we need to do to manage it is to manipulate the general level of fiscal and monetary policy. If this is done right, all that elegant $19^{\text {th }}$ century economics will be valid and individual markets can be left to take care of themselves. In effect, Samuelson told his colleagues: 'Face it - you live in a world where virtually nobody has any faith in this laissez faire religion of yours. I am offering a substitute ideology which concedes the inability of a competitive economy to take care of itself, but which also offers a management system which is, say, 95\% consistent with laissez faire'. These were hard times, and this was too good a deal to pass up. We took it. So did society as a whole. What I meant by saying that Keynesian economics is dead ... is just that this middle ground is dead. Not because people do not like the middle ground anymore but because its intellectual rationale has eroded to the point where it is no longer serviceable. (Lucas Archives Box 22, Lucas's emphasis).

Lucas's declaration that Keynesianism was dead did not suffice to kill it. Traditional Keynesians thoroughly rejected Lucas's program. To them, it "replaced messy truth by precise error" (Lipsey 2000, 76). For their part, a younger fringe of Keynesian economists - the so-called 'new Keynesian' economists, who actually constituted a disparate family - took a more positive attitude by admitting that some of Lucas's criticisms were well founded and could not be dismissed with a sweep of the hand. ${ }^{24}$ For all their differences, new Keynesians shared the view that their models should be based on what Lucas has called the 'equilibrium discipline', i.e. that sound macro requires explicit choice-theoretical foundations. They also accepted the rational expectations assumption. The challenge they had then to address was to write down models combining on the one hand optimizing behavior and rational expectations, and on the other, market non-clearing.

The vision of first generation new Keynesian macroeconomics can be described along the line we used to characterize the Keynesian vision:

- The short period functioning of the economy is the main concern

\footnotetext{
22 "To ask why the monetary theorists of the 1940s did not make use of the contingent-claim view of equilibrium is, it seems to me, like asking why Hannibal did not use tanks against the Romans instead of elephants" (Lucas [1980] 1981, 286).

${ }^{23}$ Lucas's talk was published in the alumni magazine, Issues and Ideas, in 1980. No copies of this article seem to have survived, but Lucas's preparatory notes for this talk, which seem to come close to what the published article must have been, can be found in the Lucas Archives held at David M. Rubenstein Rare Book \& Manuscript Library, Duke University.

${ }^{24}$ We shall call them 'first generation new Keynesians' to distinguish them from 'second generation new Keynesians' associated with DSGE modeling. Many of their works were collected in Gregory Mankiw and David Romer totemic twovolume book, New Keynesian Economics (Mankiw and Romer 1991).
} 
- Its main objective is to explain involuntary unemployment/underemployment and/or real effects of economic policy and inflation

- There is no longer a single baseline model.

- Central concepts are involuntary unemployment (or underemployment), wage and price rigidities, imperfect competition, (stable) Phillips curve.

- Expectations are rational.

- A Walrasian conception of microfoundations.

- Eclecticism in empirical assessment, if any.

- Demand activation is the favored policy actions.

- Adherence to the neoclassical synthesis in the fourth meaning of the term.

Here the Walrasian conception of microfoundations replaces the Marshallian one. That is, we have a shift from optimizing planning to optimizing behavior, and, moreover, the acceptance that methodological correctness implies that the analysis should start with individual decision-making. The last item in our list is also worth emphasizing: to both old Keynesians and first generation new Keynesians, the neoclassical synthesis bears on the link to be established between short- and long-period analyses. However, there is an important difference. Old Keynesians were striving at effectively constructing such a link. In contrast, first generation new Keynesians, implicitly admitting the failure of earlier attempts, hold that it is preferable to have the two strands existing side by side rather than having one of them absorbing the other: they favored an eclectic macroeconomics instead of having a single all-purpose model as proposed by Lucas and real business cycle macroeconomists. In effect, the very characterization of the (first generation) new Keynesian project proposed by Mankiw is that it arose as a reaction to the new classical assault on the (old) neoclassical synthesis:

As a matter of science, there was much success in this research [new Keynesian macro] (although, as a participant, I cannot claim to be entirely objective). The work was not revolutionary, but it was not trying to be. Instead, it was counterrevolutionary: its aim was to defend the essence of the neoclassical-Keynesian synthesis from the new classical assault. (Mankiw 2006, 36-7)

While Lucas's declaration of death of Keynesianism was premature, it is true that the emergence of a new classical macro led to the downfall of the Keynesian consensus. Now two rival visions of macroeconomics, the first generation new Keynesian vision and the new classical vision (soon to become the RBC position), disputed the field daggers drawn. This went along with a change in the power structure within the macro community with traditional Keynesians pushed towards the exit and the new Keynesians relegated to the role of Her Majesty's Opposition. ${ }^{25}$

\section{The new neoclassical synthesis}

The new neoclassical synthesis term was coined by Goodfriend and King (1997), contemporaneously with the type of modeling it refers to, the DSGE model. Goodfriend and King did not expand on what they meant by the 'old' synthesis (they wrote no more than what we mentioned earlier: that it corresponded to the macroeconometric models à la Klein), nor did most of the authors who borrowed the new neoclassical terminology from them. They all took for granted that there was an old synthesis, the meaning of which was clear to everybody.

Be that as it may, the 'new neoclassical synthesis' notion rings well. It suggests that a consensus exists in a field usually marked by schisms (Duarte 2012), and has, moreover, the discrete charm attached

\footnotetext{
${ }^{25}$ Mankiw broad plea for the new Keynesian project runs as follows: "The neoclassical-Keynesian synthesis is coherent, but it is also vague and incomplete. While the new classical economists responded to these defects by rejecting the synthesis and starting afresh, the new Keynesian economists thought there was much to preserve. Their goal was to use the tools of microeconomics to give greater precision to the uneasy compromise reached by early Keynesians. The neoclassical-Keynesian synthesis was like a house built in the 1940s. The new classicists looked at its outdated systems and concluded it was a tear down, while the new Keynesians admired the old-world craftsmanship and embraced it as an opportunity for a major rehab" (Mankiw 2006, 35). The vagueness of Mankiw's use of the neoclassical term is worth noticing. He calls 'synthesis' what we have called 'vision'. Moreover, he does not separate the Keynesian from the new Keynesian vision putting the both of them under the same 'neoclassical synthesis' mantle.
} 
to enterprises of reviving some antiquarian past. Nonetheless, it has not become the standard denomination (though Figure 1 registers an increase in the use of the term neoclassical synthesis in the early 2000s which is most likely associated with the new terminology), the most usual denominations being either DSGE or new Keynesian modeling. ${ }^{26}$

Before comparing the two syntheses, it is useful to briefly remind the main features of the basic DSGE model. ${ }^{27}$ It is an outgrowth of the real business cycle model with three important modifications. The first is the replacement of the perfect competition with the monopolistic competition assumption, which is introduced through product differentiation. In the canonical version of this model, the economy comprises possibly four types of goods: labor, a final all-purpose good (the intermediate goods aggregated through the so-called Dixit-Stiglitz aggregator), a continuum of intermediate goods, and money (at least as unit of account, not necessarily as means of exchange). The final good is a homogenous good produced under perfect competition. Intermediary goods are each produced by a monopolistic firm using only labor as input. These monopolistic firms are price-makers applying a markup on their marginal costs. The second difference with the RBC model is price sluggishness as usually accounted for by Calvo pricing: at each period, firms are allowed to choose their prices as soon as they receive a signal, occurring exogenously with a given probability (which is independent of the last time that a firm chose its price and of the state of the economy). The third departure from the RBC literature is the return of the role of monetary policy over the cycle, which brought back concerns on defining an optimal monetary policy. One way of defining monetary policy in these models is by stating that the central bank sets its instrument, the nominal interest rate (and not a monetary aggregate), by following a 'Taylor rule': the interest rate responds to (a) the difference between the observed and the targeted rate of inflation, (b) the output gap, the deviation of effective output from its natural level (the one that would have occurred had prices been flexible), and (c) a monetary shock, a random disturbance unrelated with either inflation or output gaps. ${ }^{28}$ Therefore, the baseline DSGE model results in a system of three equations: the dynamic IS equation, the New Keynesian Phillips curve and the monetary policy rule.

The DSGE model is often called the 'new Keynesian model'. Does this mean that the counterpart of Keynesians' adhesion to the real business cycle methodology has been the rehabilitation of Keynesian policy recommendations in a framework that originally implied no room for them? Simplifying the matter and taking 'Keynesian policy views' to mean demand activation, we shall now show that while the Keynesian consensus of the 1950s and 1960s was on using demand activation to reach full employment, the DSGE consensus is on using it to achieve price level stabilization, which in turns stabilizes output at its natural level.

In the basic DSGE model, there is price dispersion across the different producers of the intermediate goods because not all producers optimize their prices every period. This price dispersion generates output dispersion: every period there are producers that are forced to produce inefficient levels of intermediate goods because their prices differ from the average price level. To minimize such inefficiency and maximize welfare, the monetary authority should stabilize the price level: if the inflation rate is zero, the firms who are allowed to optimally set their prices will choose not to do so; therefore there will be no price dispersion across different producers no matter who was allowed to reset prices optimally. Without price dispersion, all firms will produce the same amount of intermediate goods and the overall economy will behave as if as prices were flexible. Thus, current output will coincide with its natural level the determination of which depends on the standard factors emphasized in RBC theory. ${ }^{29}$ Thus, as in the RBC world, fluctuations that result from shocks that move the natural level of output are efficient, and

\footnotetext{
${ }^{26}$ Both terms have their drawbacks. Strictly speaking, the DSGE term applies as well to new classical and RBC modeling. Why then confining it to the third wave of models rather than to the broader modeling strategy? As to the new Keynesian adjective, not all DSGE economists will like to be put under this label. Moreover, it puts aside the distinction between 'first generation' new Keynesian models and 'second generation' Keynesian models, i.e. DSGE models.

${ }^{27}$ See Duarte (2011) and references therein for a detailed exposition of this model.

${ }^{28}$ The Taylor rule usually includes the lagged value of the nominal interest rate for capturing interest rate smoothing from the central bank.

${ }^{29}$ Here, then, there is no tradeoff between stabilizing prices and stabilizing the gap between current output and its desired level - what Blanchard and Galí (2007) called the 'divine coincidence' (and felt the need to remove from their new Keynesian model).
} 
monetary authority should do nothing to stabilize them (see also Kocherlakota 2010, 10). However the new Keynesians insist that the RBC world is not complete: there are also fluctuations that are inefficient because of price stickiness, and here the government has a stabilization role to play (Woodford 2003, 5).

The DSGE vision of macroeconomics can be sketched out against the same broad criteria we used for characterizing the Keynesian and the new Keynesian visions:

- Macroeconomics aims at explaining business cycle fluctuations, with a particular emphasis on monetary and fiscal policies and inflation.

- The baseline model is the neoclassical growth model with market imperfections and rigidities (DSGE model).

- Central concepts: market clearing, intertemporal substitution, price and wage rigidities, market imperfections and distortions.

- Rational expectations.

- A Walrasian conception of microfoundations.

- Empirical assessment proceeds through a combination of estimation and calibration of models.

- Consensus on a monetary policy that stabilizes the price level.

- The unwitting rejection of the 'old' neoclassical synthesis.

The last item requires a commentary. As already stated, old Keynesian and first generation new Keynesian economists shared the belief that macroeconomics should be composed of two sub-areas dealing with the short and the long periods. The former consisted of market non-clearing models, the latter of market clearing models. DSGE economists reject this understanding and adhere to the Lucasian conception of a homogenous macro research program. This marks an important difference between first and second generation new Keynesians that has been little noticed. To wit, Godfriend and King write, "We call the new style of macroeconomic research the new neoclassical synthesis because it inherits the spirit of the old synthesis" (Godfriend and King 1997, 255). Contrary to this understanding, we argue that the new synthesis (a new Keynesian/RBC one) bears little resemblance with the Keynes/Walras synthesis (be it the Keynes/Walras synthesis à la Patinkin or the new Keynesian/Walras 'non synthesis' à la Solow/Mankiw).

The DSGE vision of macroeconomics is the last installment (to date) in the series of visions encountered earlier (the Keynesian vision, the Lucasian-real business cycle vision and the first generation new Keynesian vision). What is new with respect to the earlier situation is that, after the phase of struggle between two rival visions, a harmonious state of affairs has re-emerged, the DSGE consensus. For economists such as Blanchard $(2009,210)$ a feeling of relief ensued:

... [A]fter the explosion (in both the positive and negative meaning of the word) of [macroeconomics] in the 1970s, there has been enormous progress and substantial convergence. For a while - too long a while - the field looked like a battlefield. Researchers split in different directions, mostly ignoring each other, or else engaging in bitter fights and controversies. Over time however, largely because facts have a way of not going away, a largely shared vision both of fluctuations and of methodology has emerged.

Table 1 below gives an overview of the transformation incurred by macroeconomics as far as consensus, vision and synthesis are concerned.

\section{Insert Table 1 here}

We would like to make two final points before concluding. First, let us ask ourselves how well the old and the new neoclassical syntheses each abide with our notion of a synthesis, i.e. the merging of two theories that before were considered independent and possibly antagonistic. We have seen that as far as the old synthesis is concerned, little was delivered in this respect with exception of non-Walrasian equilibrium models. In its main understanding, the neoclassical synthesis consists of refusing to establish a synthesis. In sharp contrast, the new synthesis designates the successful merging of two theoretical streams, RBC and (first generation) new Keynesian modeling, that before were considered alien to each other. In this merging, each of the two parties abandoned central tenets of their earlier views. RBC economists gave away perfect competition, flexible price and the classical dichotomy. New Keynesians 
forwent the query for a theory of involuntary unemployment and, crucial for our inquiry, the neoclassical synthesis standpoint since they now accept to reason in terms of a single modeling strategy. ${ }^{30}$

A second observation is that not all first generation economists have followed suite with Blanchard accepting to ride the DSGE horse. Solow (2010) and Mankiw (2006), although glad to see the themes of rigidity and imperfect competition returning to the forefront, remain nonetheless lukewarm about the DSGE modeling. ${ }^{31}$ The reason for Solow's and Mankiw's attitude, we suggest, lays with their desire to stick to the defense of a pluralistic macroeconomics.

\section{Concluding remarks}

Branding an approach as 'new' with respect to some previously existing one triggers the desire of recapturing the content of the ancestral version. This was the aim pursued in this paper with respect to the genealogy of the new neoclassical synthesis. The result of this inquiry is that the clear meaning of the new neoclassical synthesis notion does not extend to that of the old neoclassical synthesis. In terms of usage, the latter has a backreading existence: the term was scarcely used at the time when it was supposed to be reigning. Moreover, when asking ourselves whether the 'thing' existed in spite of the thin existence of the label, we realized that the neoclassical synthesis expression was used in very different meanings. The task addressed in the paper has been to scrutinize that expression and its uses.

First of all, we have thought it useful to be strict on definitions. Therefore we opted for a narrow definition of a synthesis: it designates a merger between theories that before had independent identities and were deemed to be incompatible. We have also taken care of separating the notions of synthesis and consensus, which are often blurred. This groundwork accomplished, we have disentangled the main conceptions in which the neoclassical synthesis program has been envisaged within the Keynesian vision of macroeconomics. They can be classified on two scores. As far as their abiding by our definition of a synthesis is concerned, two of them fare well (the gravitational and the side by side modeling interpretations). The two remaining ones (the IS-LM and the Klein-Goldberger interpretations) ought to be dismissed. But gauging them in terms of adhesion, the two most popular were, we guess, the IS-LM and the side by side modeling interpretations. At the end of our exploration, we have come to the conclusion that the side by side conception is the most cogent one in spite of its being semantically twisted as it consists in a refusal of establishing a synthesis between Keynesian and Walrasian theory.

Next, we discussed how Lucas vindicated the dismissal both of the neoclassical synthesis and of the Keynesian consensus. We exposed how his criticism triggered the arising of a modified Keynesian vision, the new Keynesian vision, which we found important to qualify as the first generation new Keynesian vision in order to contrast it with the second generation new Keynesian vision associated with DSGE modeling. The defenders of this vision tried to counteract Lucas's by admitting to posit problems in his way, i.e. adopting the Walrasian microfoundations requirement instead of the Marshallian one. But they were on all four with traditional Keynesian as far as it came to put them under the neoclassical banner. This was an age, going from the mid-seventies to the mid-nineties, were no consensus any longer existed among macroeconomists, when the field was ridden with a strong rivalry between (first generation) new

\footnotetext{
${ }^{30}$ From the three equations that characterize the baseline DSGE model we can easily see the merging of features of the RBC and new Keynesian models: from the former we have the intertemporal allocation of consumption and output described by the IS equation, something that was absent in the static models that characterized the first wave of new Keynesian literature. From this literature the DSGE model exhibits both price stickiness (that generate the new Keynesian Phillips curve) and a description of the monetary policy (the Taylor rule) with a clear characterization of a monetary shock, both elements that were absent in the first generation of RBC models. Besides, the concept of a natural level of output comes from the RBC literature and it provides "a useful summary of the way in which disturbances" affect the economy independently of prices being constantly adjusted or not (Woodford 2003, 152). So we can see how central to the DSGE literature a synthesis between those two groups is.

${ }^{31}$ In his usual witty way, Solow notes that "The more adventuresome advocates of RBC theory have found it necessary to modify many of the clean but extreme assumptions that give formal general equilibrium theory its artificial vanilla flavor. ... It has come closer and closer to the more or less 'Keynesian' model it was supposed to discredit" (Solow 1997a, 52-3). As to Mankiw, he has the following to say: "Perhaps what has occurred is not so much a synthesis as a truce between intellectual combatants, followed by a face-saving retreat on both sides. Both new classicals and new Keynesians can look to this new synthesis and claim a degree of victory; while ignoring the more profound defeat that lies beneath the surface" (Mankiw 2006, 39).
} 
Keynesian and new classical (and real business cycle) economists. This state of affairs ended as the result of the new neoclassical synthesis, which allowed the arising of a new consensus, the DSGE consensus. Here two features stand out. First, in contrast to what was the case with the old synthesis, the new synthesis constitutes an achieved synthesis. Second, terminology to the contrary notwithstanding, it is not an extension of the old synthesis: the second generation new Keynesian economists of the DSGE era have abandoned the old neoclassical synthesis viewpoint, which is probably the main reason for Solow's and Mankiw's reluctance to come on board.

\section{References}

Ackley, Gardner (1961). Macroeconomic Theory. New York: Macmillan.

Arrow, Kenneth (1967). Samuelson Collected. Journal of Political Economy, 75(5):730-37.

Aspromourgos, Tony (1986). On the Origins of the Term 'Neoclassical'. Cambridge Journal of Economics, 10(3):265-70.

Barro, Robert J. (1987). Macroeconomics. $2^{\text {nd }}$ ed. New York: John Wiley \& Sons.

Barro, Robert J., and Herschel I. Grossman (1971). A General Disequilibrium Model of Income and Employment. American Economic Review, 61(1):82-93.

Benassy, Jean-Pascal (1975). Neo-Keynesian Disequilibrium Theory in a Monetary Economy. Review of Economic Studies, 42(4):503-23.

Blanchard, Olivier J. (2009). The State of Macro. Annual Review of Economics, 1, 209-28.

Blanchard, Olivier J., and Jordi Galí (2007). Real Wage Rigidities and the New Keynesian Model. Journal of Money, Credit and Banking, 39(1):35-65.

Branson, William H. (1972). Macroeconomic Theory and Policy. New York: Harper \& Row.

Branson, William H., and James M. Litvack (1981). Macroeconomics. $2^{\text {nd }}$ ed. New York: Harper \& Row.

Bronfenbrenner, Martin (1966). Trends, Cycles, and Fads in Economic Writing. American Economic Review, 56(1-2):538-52.

Campbell, Robert (1963). Reviewed of "Main Currents in Modern Economics" by Ben B. Seligman. American Economic Review, 53(1, P.1):174-76.

Colander, David (2006). Post-Walrasian macroeconomics; some historical link. In D. Colander (ed.), Post-Walrasian Macroeconomics. Beyond the Dynamic Stochastic General equilibrium Model, Cambridge: Cambridge University Press, pp. 46-69.

De Vroey, Michel (2009). A Marshall-Walras Divide? A Critical Review of the Prevailing Viewpoints. History of Political Economy, 41(4):709-36.

De Vroey, Michel, and Pierre Malgrange (2012). From The Keynesian Revolution to the KleinGoldberger Model: Klein and the Dynamization of Keynesian Theory. History of Economic Ideas, (forthcoming).

Denburg, Thomas F., and Duncan M. McDougall (1963). Macro-Economics - the measurement, analysis, and control of aggregate economic activity. $2^{\text {nd }} \mathrm{ed}$. New York: McGraw-Hill.

Donzelli, Franco (2007). Equilibrium and tâtonnement in Walras's Elements. History of Economic Ideas, 15(3):83-138.

Dornbush, Rudiger, and Stanley Fischer (1990). Macroeconomics. $5^{\text {th }}$ ed. New York: McGraw-Hill.

Drèze, Jacques H. (1975). Existence of Equilibrium under Price Rigidities International Economic Review, 16(2):301-20.

Duarte, Pedro Garcia (2011). Recent Developments in Macroeconomics: The DSGE Approach to Business Cycles in Perspective. In John B. Davis and D. Wade Hands (eds), The Elgar Companion to Recent Economic Methodology. Cheltenham, UK: Edward Elgar, pp. 375-403.

Duarte, Pedro Garcia (2012). Not going away? Microfoundations in the making of a new consensus in macroeconomics. In Pedro Garcia Duarte and Gilberto Tadeu Lima (eds.), Microfoundations Reconsidered - The Relationship of Micro and Macroeconomics in Historical Perspective. Cheltenham,UK: Edward Elgar, pp. 190-237.

Fand, David (1969). Keynesian Monetary Theories, Stabilization Policy, and the Recent Inflation. Journal of Money, Credit and Banking, 1(3):556-87. 
Giraud, Yann (2011). The Political Economy of Textbook Writing: Paul Samuelson and the Making of the First Ten Editions of Economics (1945-1976). Working Paper, available at SSRN: http://papers.ssrn.com/sol3/papers.cfm?abstract_id=1913766.

Goodfriend, Marvin, and King, Robert G. (1997). The New Neoclassical Synthesis and the Role of Monetary Policy. NBER Macroeconomics Annual, 12: 231-83.

Gordon, Robert J. (1978). Macroeconomics. Boston: Little, Brown and Company.

Hall, Robert E., and John B. Taylor (1991). Macroeconomics - theory, performance, and policy. $3^{\text {rd }} \mathrm{ed}$. New York: W. W. Norton.

Hicks, John (1932). The Theory of Wages. $1^{\text {st }}$ ed. London: MacMillan.

Howitt, Peter (1987). Macroeconomics: Relation with Microeconomics. In John Eatwell, M. Milgate and Peter Newman (eds.), The New Palgrave: A Dictionary of Economics, vol. 3, London: MacMillan, pp. 273-75.

Hymer, Stephen (1968). Review of "The Teaching of Development Economics" by Kurt Martin and John Knapp. Journal of Finance, 23(4):719-21.

Johnson, Harry G. (1954). Review of "A Review of Economic Doctrines, 1870-1929" by T. W. Hutchinson. Economic History Review, 6(3):326.

Jorgenson, Dale W. (1964). Review of "The Theory of General Economic Equilibrium" by Robert E. Kuenne. Journal of Business, 37(3):311-12.

Klamer, Arjo (1984). The New Classical Macroeconomists. Conversations with the New Classical Economists and their Opponents. Brighton: Wheatsheaf.

Klein, Lawrence (1947). The Keynesian Revolution, New York: MacMillan.

Klein, Lawrence (1955). The Empirical Foundations of Keynesian Economics. In Kenneth K. Kurihara (ed.), Post Keynesian Economics. London: Allen and Unwin, pp. 277-319.

Klein, Lawrence and Arthur Goldberger (1955). An Econometric Model of the United States, 1929-1952. Amsterdam: North Holland.

Kocherlakota, Narayana (2010). Modern Macroeconomic Models as Tools for Economic Policy. The Region, May 2010:5-21.

Lange, Oskar (1938). The Rate of Interest and the Optimum Propensity to Consume. Economica, $5(17): 12-32$.

Leijonhufvud, Axel (1968). On Keynesian Economics and the Economics of Keynes, Oxford: Oxford University Press.

Leijonhufvud, Axel (2006). Agent-Based Macro. In L. Tesfatsion and K. Judd (eds.), Handbook of Computational Economics, Vol. II, Elsevier, pp. 1625-37.

Loasby, Brian J. (1971). Hypothesis and Paradigm in the Theory of the Firm. Economic Journal, 81(324):863-85.

Lucas, Robert E., Jr. (1976). Econometric Policy Evaluation: A Critique. Carnegie-Rochester Conference Series on Public Policy, 11, 19-46.

Lucas, Robert E., Jr. ([1980] 1981). Methods and Problems in Business Cycle Theory. In R. Lucas, Studies in Business Cycle Theory. Cambridge, MA: The M.I.T. Press, pp. 271-96.

Lucas, Robert E., Jr. (1987). Models of Business Cycle. Oxford: Basil Blackwell.

Lucas, Robert E., Jr., and Thomas. J. Sargent (1979). After Keynesian Macroeconomics. The Federal Reserve Bank of Minneapolis Quarterly Review, 3 (2).

Lipsey, Richard G. (2000). IS-LM, Keynesianism, and the New Classicism. In Roger Backhouse and Andrea Salanti (eds), Macroeconomics and the Real World, vol. 2 Keynesian Economics, Unemployment and Policy. Oxford University Press, pp. 57-82.

Malinvaud, Edmond (1977). The Theory of Unemployment Reconsidered. Oxford: Basil Blackwell.

Mankiw, N. Gregory (2006). The Macroeconomist as Scientist and Engineer. Journal of Economic Perspectives, 20 (4):29-46.

Mankiw, N. Gregory and David Romer (eds.) (1991). New Keynesian Economics. Cambridge, MA: MIT Press.

Marshall, Alfred (1920). Principles of Economics. $8^{\text {th }}$ ed. London: Macmillan. 
McKenna, Edward, and Diane Zannoni (1997), Neoclassical Synthesis (Bastard Keynesianism). In Thomas Cate (ed.), An Encyclopedia of Keynesian Economics. Cheltenham: Routledge, pp. 463-7.

Patinkin, Don (1956). Money, Interest and Prices. $1^{\text {st }}$ ed. New York: Harper and Row.

Pearce, Kerry A., and Kevin D. Hoover (1995). After the Revolution: Paul Samuelson and the Textbook Keynesian Model. In Allin R. Cottrell and Michael S. Lawlor (eds.), New Perspectives on Keynes. History of Political Economy, annual supplement to vol. 27. Durham, NC: Duke University Press.

Samuelson, Paul A. (1947). Foundations of Economic Analysis. Cambridge, MA: Harvard University Press.

Samuelson, Paul A. ([1951] 1966). Principles and Rules in Modern Fiscal Policy: A Neo-Classical Reformulation. In Joseph E. Stiglitz (ed.), The Collected Scientific Papers of Paul A. Samuelson, vol. 2. Cambridge, MA: The MIT Press, pp. 1271-90.

Samuelson, Paul A. (1952). Economic Theory and Mathematics - An Appraisal. American Economic Review, 42(2):56-66.

Samuelson, Paul A. (1955). Economics. $3^{\text {rd }}$ ed. New York: McGraw-Hill.

Samuelson, Paul A. ([1963] 1966). A Brief Survey of Post-Keynesian Developments. In Joseph E. Stiglitz (ed.), The Collected Scientific Papers of Paul A. Samuelson, vol. 2. Cambridge, MA: The MIT Press, pp. 1534-50.

Samuelson, Paul A. (1997). Credo of a Lucky Textbook Author. Journal of Economic Perspectives, 11(2):153-60.

Sen, Amartya K. (1962). Review of "The Rich and the Poor - A Study of the Economics of Rising Expectations" by R. Theobald. Economic Journal, 72(287):695-97.

Smith, Warren L. (1970). Macroeconomics. Homewood, Illinois: Richard D. Irwin.

Snowdon, Brian, and Howard Vane (1995). New-Keynesian Economics Today: The Empire Strikes Back. American Economist, 39(1):48-65.

Snowdon, Brian, and Howard Vane (1999). Robert Solow. In B. Snowdon and H. Vane, Conversations with Leading Economists. Chentelham: Edward Elgar, pp. 270-91.

Solow, Robert (1997a). How Did Economics Get That Way and What Way Did It get? Daedalus, 126(1):39-58.

Solow, Robert (1997b). Swan Trevor, W. In Thomas Cate (ed.), An Encyclopedia of Keynesian Economics. Cheltenham: Routledge, pp. 594-7.

Solow, Robert (2001). From Neoclassical Growth Theory to New Classical Macroeconomics. In Jacques Drèze (ed Advances in Macroeconomic Theory, IEA conference volume 133. Basingstoke: Palgrave, pp. 19- 29.

Solow, Robert (2008). The State of Macroeconomics. Journal of Economic Perspectives, 22(1):243-6.

Solow, Robert (2010). Building a Science of Economics for the Real World. House Committee on Science and Technology, U.S. House of Representatives - Subcommittee on Investigations and Oversight. July 20. Washington, D. C. (available at:

http://science.house.gov/publications/hearings_markups_details.aspx?NewsID=2916, accessed on May 15, 2011).

Stigler, George J. (1941). Production and Distribution Theories. New York: Macmillan.

Tarascio, Vincent J. (1974). Vilfredo Pareto and the Translation of His Manuel. Journal of Economic Literature, 12(1):91-96.

Tobin, James (1992). An old Keynesian Counterattacks. Eastern Economic Journal, 18(4):387-400.

Weintraub, E. Roy (1974). General Equilibrium Theory. Macmillan Studies in Economics. London: Macmillan.

Weintraub, E. Roy (1991). Stabilizing Dynamics: Constructing Economic Knowledge. Cambridge: Cambridge University Press.

Wiles, Peter (1973). Cost Inflation and the State of Economic Theory. Economic Journal, 83(330):37798.

Woodford, Michael (1999). Revolution and Evolution in Twentieth Century Macroeconomics. Presented at a conference, Frontiers of the Mind in the Twenty-First Century, U.S. Library of Congress, Washington, D.C., June 1999. (Available at: http://www.columbia.edu/ mw2230/).

Woodford, Michael (2003). Interest and Prices: Foundations of a Theory of Monetary Policy. Princeton: Princeton University Press. 
Table 1: The evolution of syntheses, visions and consensuses over the history of macroeconomics

\begin{tabular}{|c|c|c|c|c|}
\hline & \multirow{2}{*}{$\begin{array}{l}\text { The Keynesian consensus: } \\
\text { the predominance of the } \\
\text { Keynesian vision of } \\
\text { macroeconomics } \\
\text { (mid 1940s to mid 1970s) }\end{array}$} & \multicolumn{2}{|c|}{$\begin{array}{l}\text { The rivalry between the first generation new } \\
\text { Keynesian and the new classical visions (mid } \\
1970 \text { s to mid 1990) }\end{array}$} & \multirow{2}{*}{$\begin{array}{l}\text { The DSGE consensus: } \\
\text { the predominance of } \\
\text { the DSGE vision (mid } \\
1990-. . \text { ) }\end{array}$} \\
\hline & & $\begin{array}{c}\text { The vision of first } \\
\text { generation new Keynesian } \\
\text { macro }\end{array}$ & $\begin{array}{l}\text { The new classical } \\
\text { vision }\end{array}$ & \\
\hline Time conception: & $\begin{array}{l}\text { - a split between short- } \\
\text { and long- period analysis, } \\
\text { the former being the main } \\
\text { concern of } \\
\text { macroeconomics }\end{array}$ & $\begin{array}{l}\text { - a split between short- } \\
\text { and long- period analysis, } \\
\text { the former being the main } \\
\text { concern of } \\
\text { macroeconomics }\end{array}$ & $\begin{array}{l}\text { - time as a } \\
\text { succession of points } \\
\text { with possible } \\
\text { departures from } \\
\text { trend }\end{array}$ & $\begin{array}{l}\text { - time as a succession } \\
\text { of points with } \\
\text { possible departures } \\
\text { from trend }\end{array}$ \\
\hline Market outcome & - market non-clearing & - market non-clearing & - market clearing & - market clearing \\
\hline $\begin{array}{l}\text { Microfoundations } \\
\text { conception }\end{array}$ & - Marshallian & - Walrasian & - Walrasian & - Walrasian \\
\hline Type of synthesis & - neoclassical synthesis & - neoclassical synthesis & - none & $\begin{array}{l}\text { - new neoclassical } \\
\text { synthesis }\end{array}$ \\
\hline $\begin{array}{l}\text { Content of the } \\
\text { synthesis }\end{array}$ & $\begin{array}{l}\text { - several coexisting } \\
\text { meanings }\end{array}$ & $\begin{array}{l}\text { - defense of a pluralistic } \\
\text { macroeconomics }\end{array}$ & - none & $\begin{array}{l}\text { - merging of new } \\
\text { Keynesian and RBC } \\
\text { premises }\end{array}$ \\
\hline
\end{tabular}

